\title{
$\begin{array}{lllllllllllllllll}\mathbf{K} & \mathbf{O} & \mathbf{M} & \mathbf{U} & \mathbf{N} & \mathbf{I} & \mathbf{K} & \mathbf{A} & \mathbf{T} & \mathbf{Y} & \mathbf{N} & \mathbf{A} & \mathbf{U} & \mathbf{K} & \mathbf{O} & \mathbf{W} & \mathbf{E}\end{array}$ \\ KWARTALNIK HISTORII KULTURY MATERIALNEJ 68 (1), 2020 \\ PL ISSN 0023-5881 \\ www.iaepan.edu.pl \\ DOI: 10.23858/KHKM68.2020.1.007
}

Karolina Blusiewicz

\section{Dwa nietypowe buty z Pucka z końca XIV wieku}

\begin{abstract}
Słowa kluczowe: Puck, obuwie późnośredniowieczne, konstrukcja wywracano-pasowa, podeszwa kołkowana
\end{abstract}

Key words: Puck, medieval footwear, turn-welt construction, wood-pinned outer sole

Badania archeologiczne prowadzone w historycznych centrach średniowiecznych miast dostarczają licznych źródeł do badań nad kulturą materialną i wytwórczością ich mieszkańców w przeszłości. W przypadku prostych wyrobów rzemieślniczych, wykonanych z łatwo dostępnego surowca, powszechnie używanych i związanych z zapewnieniem podstawowych potrzeb mieszczan przyjmuje się, że znaleziska te wytworzone zostały na miejscu. Dopiero w toku szczegółowej analizy zbioru pozyskanych zabytków ruchomych możliwe jest wyodrębnienie przedmiotów, których cechy szczególne, takie jak nietypowy surowiec, cechy morfologiczne lub zdobienie wyróżniają je od pozostałych i wskazują na ich ewentualne pochodzenie z innego, niekoniecznie miejscowego warsztatu.

Podobne założenie przyjęte zostało dla znalezisk późnośredniowiecznych wyrobów ze skóry wydobywanych na terenie miasta lokacyjnego w Pucku. Domniemanie lokalnego pochodzenia wyrobów potwierdziły skupiska odpadów produkcyjnych, będące niewątpliwie świadectwem istnienia miejscowych warsztatów skórniczych, zaś charakterystyczne odpady ze skóry podeszwowej - ich szewskiego charakteru ${ }^{1}$. Produkcja małomiasteczkowych szewców przeznaczona była przede wszystkim na zaspokojenie potrzeb rynku wewnętrznego oraz wymianę handlową z lokalnym zapleczem wiejskim. Nie można jednak wykluczyć napływu wyrobów szewskich z sąsiadujących małych miast lub sprowadzanych z większych ośrodków handlowych ${ }^{2}$, a także wytworów rzemiosła wiejskiego, które mimo licznych obostrzeń prezenikały na rynki miejskie ${ }^{3}$. Oczywiste jest także, że pewna część znajdowanych przedmiotów mogła dotrzeć z różnych stron wraz z przybyszami odwiedzającymi miasto. Określenie miejsca produkcji znalezionego w trakcie wykopalisk obuwia jest kwestią na ogół niemożliwą do rozstrzygnięcia. Z konieczności zatem, lecz nie bezpodstawnie, przyjmuje się a priori ich miejscowe pochodzenie, o ile nie istnieją wyraźne przesłanki do przeciwnego stwierdzenia.

Obuwie wydobyte z późnośredniowiecznych nawarstwień miasta lokacyjnego w Pucku w większości reprezentuje formy typowe dla tego okresu, pospolite pod względem stylistycznym i konstrukcyjnym, których wykonanie nie wykraczało poza możliwości szewców puckich. Jednak lokalne pochodzenie dwóch egzemplarzy budzi wątpliwości. Oba znalezione zostały

1 Blusiewicz K. 2017.

2 Śladem takiej konkurencji może być np. zakaz zbytu towarów przez obcych kupców, m.in. puckich, wydany w Lęborku w 1542 r. na wniosek tamtejszego cechu szewskiego (Groth A. 1998, s. 157).

3 Samsonowicz H. 1954, s. 69-78. 

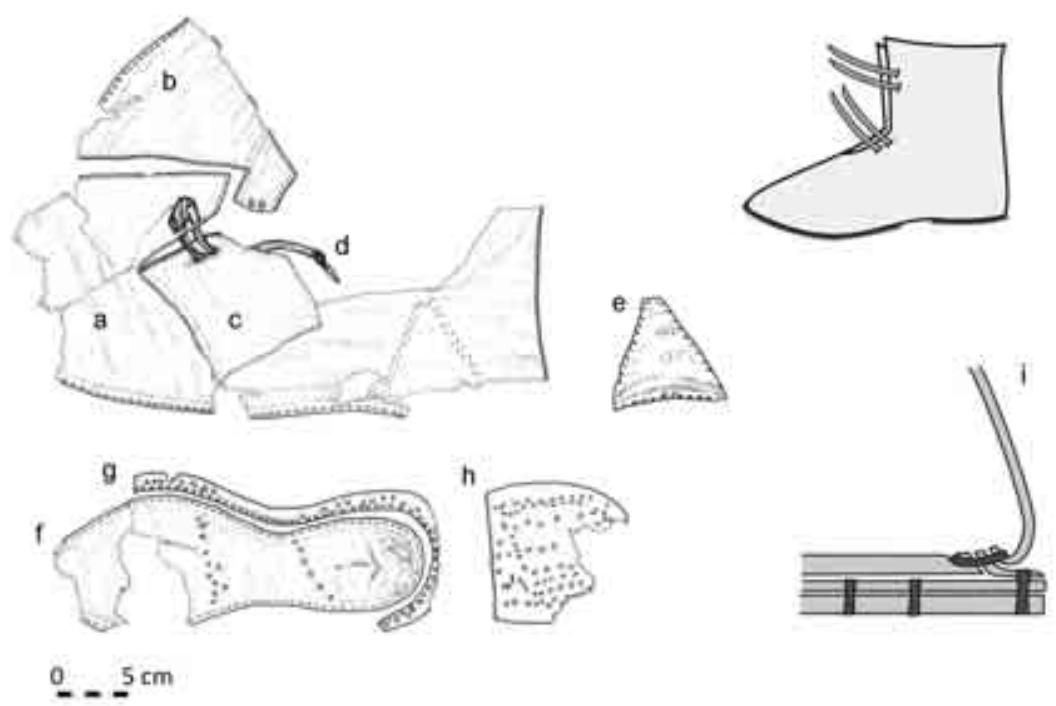

Ryc. 1. But wysoki z cholewą wiązaną sznurowadłami z czwartej ćwierci XIV w. z Pucka: a - przyszwa; b - łącznik; c - podszewka; d - sznurowadło; e - zapiętek; f - podeszwa; $\mathrm{g}$ - uszczelka; $\mathrm{h}$ - wzmocnienie zewnętrzne; $\mathrm{i}$ - rekonstrukcja łączenia przyszwy z wielowarstwowym spodem. Rys. K. Blusiewicz

Fig. 1. The shoe with a laced upper from the 4th quarter of the 14th c. from Puck: a — vamp; b - insert; c - lining; $d$ - lace; e — heel stiffener; f — sole; g — rand/welt; $\mathrm{h}$ - outer sole; $\mathrm{i}$ - the reconstruction of the joining of the vamp to the multilayer sole. Drawn by K. Blusiewicz

wśród odpadów produkcyjnych warsztatu szewskiego, którego funkcjonowanie ustalono na podstawie datowania dendrochronologicznego na ostatnią ćwierć XIV wieku ${ }^{4}$.

Pierwszy to but o dużym męskim rozmiarze, z wysoką, rozciętą z przodu cholewą, wiązaną przez pary dziurek charakterystycznymi, rozdwojonymi sznurowadłami wykonanymi z rozciętego podłużnie paska skóry (ryc. 1). Jego wierzch wykrojono ze skóry bydlęcej metodą jednokrójki z łącznikiem. W późniejszym czasie część cholewy intencjonalnie odcięto, zapewne w celu wtórnego wykorzystania surowca. Obuwie było starannie wykończone: tył wzmocniono miękkim zapiętkiem ze skóry koziej lub owczej, a górne krawędzie cholewy wykończono lamówką. But dodatkowo ocieplono, wszywając od wewnątrz podszewkę. Zachowała się w postaci warstwy mizdrowej skóry o pokroju włókien wykluczającym pochodzenie ze skóry dorosłego bydła. Podszewka ta mogła być wykonana $z$ dwoiny ${ }^{5}$ bądź też skóry licowej, której lico uległo całkowitemu odspojeniu ${ }^{6}$ — nie są widoczne ślady pozwalające na jednoznaczne oznaczenie. Zachowała się wraz z przyszwą jedynie dzięki

${ }^{4}$ Blusiewicz K. 2017, s. 306. Badania w 2007 r. przy ul. 10 Lutego 4, działka nr ew. 150.

5 Dwoina powstaje w wyniku rozcięcia płata skóry w grubości na dwoinę z mizdrą i dwoinę z licem.

${ }^{6}$ Rozwarstwianie się skóry na warstwę licową i mizdrową wśród znalezisk z badanego zbioru można często obserwować - odnotowano go w 65,9\% elementów wierzchów obuwniczych z drugiej połowy XIV w. oraz $54,6 \%$ odpadów produkcyjnych z czwartej ćwierci XIV w. ze wspomnianego warsztatu (badania własne). 


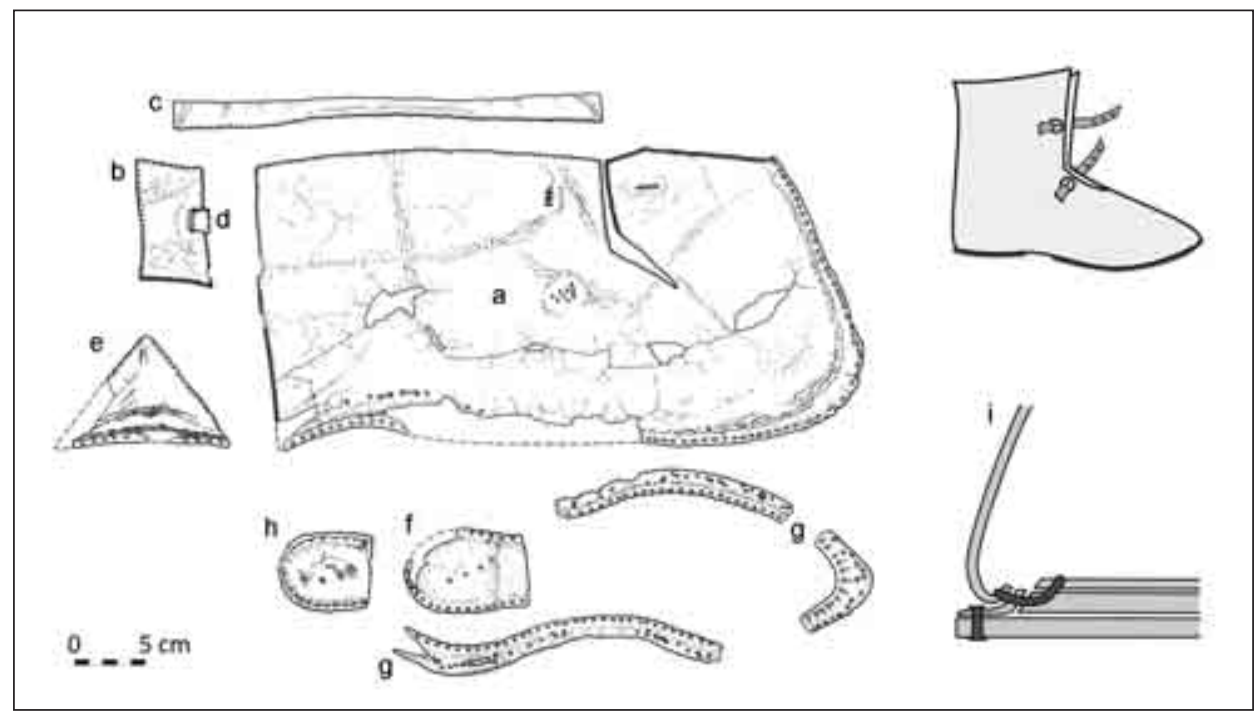

Ryc. 2. But wysoki z cholewą zapinaną paskami z czwartej ćwierci XIV w. z Pucka: a - przyszwa; b - wstawka; c - lamówka; d - pasek zapinkowy; e — zapiętek; $\mathrm{f}$ - fragment podeszwy; $\mathrm{g}$ - uszczelka; $\mathrm{h}$ - podpiętek; i — rekonstrukcja łączenia przyszwy z wielowarstwowym spodem. Rys. G. Zborowska, K. Blusiewicz

Fig. 2. The shoe with a buckled upper from the 4th quarter of the 14th c. from Puck: $\mathrm{a}$ - vamp; $\mathrm{b}$ - insert; $\mathrm{c}$ - top binding; $\mathrm{d}$ - fastening band; $\mathrm{e}$ - heel stiffener; $\mathrm{f}$ - a fragment of the sole; $g$ - rand/welt; $h$ - heel seat; $i$ - a reconstruction of the joining of the vamp to the multilayer sole. Drawn by G. Zborowska, K. Blusiewicz

przewleczonemu przez nie skórzanemu sznurowadłu, które uniemożliwiło rozdzielenie się elementów.

W szczególny sposób wzmocniony został także spód opisanego buta. Z wierzchem połączony był charakterystycznym dla okresu średniowiecza sposobem wywracanym, z uszczelką umieszczoną między przyszwą a podeszwą. W tym przypadku zastosowano szeroką uszczelkę, do której, po wywróceniu obuwia na stronę prawą, przymocowano od strony zewnętrznej dodatkowe wzmocnienia w przedstopiu i pięcie. W pozyskanym egzemplarzu zachowało się jedynie wzmocnienie pod piętą (ryc. 1h), wykrojone z grubej skóry bydlęcej, które zamocowano do uszczelki drewnianymi kołeczkami umieszczonymi po obwodzie. Ślady po kołkach na całej jego powierzchni wskazują, że prawdopodobnie składało się ono z większej liczby połączonych ze sobą warstw skóry.

Drugi z butów, również męski, miał rzadko spotykaną formę — wysoka, rozcięta z przodu cholewka zapinana była przy użyciu co najmniej dwóch pasków z dziurkami i najpewniej metalowych sprzączek (ryc. 2). Wykrojono ją ze skóry cielęcej sposobem jednokrójki ze wstawką uzupełniającą. Pozostałe elementy wykonano ze skóry pochodzącej od dorosłego bydła. Tył obuwia usztywniony został szerokim zapiętkiem, a górna krawędź cholewy zabezpieczona lamówką. Oprócz sposobu zapinania but ten wyróżniał także wielowarstwowy spód. Podeszwę wzmocniono od wewnątrz podpiętkiem oraz, podobnie jak w poprzednim egzemplarzu, po wywróceniu na stronę prawą zewnętrznymi wzmocnieniami w przedstopiu i pięcie. Niestety nie przetrwały one wraz z butem - pozostały po nich ślady w postaci drugiego rzędu regularnie rozmieszczonych otworów na szerokiej uszczelce (ryc. 2g). Ślady korozji wskazują, że 
zostały one przytwierdzone przy użyciu metalowych ćwieków. Ponadto na uszczelce wyróżniono dodatkowe, nieregularne dziurki z zachowanymi resztkami skórzanego paska, stanowiące zapewne ślad późniejszego łatania obuwia lub wymiany wzmocnienia.

Oba opisane egzemplarze stanowią przykłady rzadko notowanych w literaturze późnośredniowiecznych butów ze wzmocnioną od zewnątrz podeszwą. Wprawdzie wielowarstwowe spody odnotowywane są stosunkowo często, przeważnie jednak wzmocnienie stanowią wyłożenia wewnętrzne, w postaci podpiętków i wyściółek, wszywanych razem z podeszwą od lewej strony. Spotykane są także wykonane w sposób wywracany wzmocnienia zewnętrzne, jak w przypadku znalezisk z drugiej połowy XIV w. z lokacyjnego Kołobrzegu ${ }^{7}$. Niemniej jednak, konieczność wywrócenia buta po połączeniu podeszwy i elementów wierzchu znacznie ograniczała możliwość zastosowania sztywnego i grubego spodu w obuwiu wywracanym, co miało wpływ na słabą izolację od podłoża oraz szybkie zużywanie podeszew. Zastosowanie szerszych uszczelek umożliwiało dołączenie do podeszwy dodatkowych elementów spodu z grubej i sztywnej skóry pod częścią lub całą powierzchnią stopy, już po wywróceniu go na stronę prawą. Taki sposób wykonywania obuwia, określany jako wywracano-pasowy (turnwelt construction), do niedawna uznawano za wynaleziony w XV w., początkowo jako wynik napraw zniszczonych podeszew, a rozwinięty później do zamierzonej konstrukcji wielowarstwowego spodu ${ }^{8}$. Nowsze znaleziska, jak w przypadku butów z badań w Genewie, z dodatkowymi spodami starannie przyszytymi do szerokiej uszczelki i wewnętrznej podeszwy bez śladów zużycia pozwoliły na przesunięcie tej cezury na pierwsze dziesięciolecia XV w. ${ }^{9}$ Szerokie uszczelki z podwójnym rzędem dziurek uznawane są za prototyp pasa obuwniczego i stanowią zapowiedź zmian w technice wykonywania obuwia, jakie zaszły na przełomie stuleci XV i XVI przez wprowadzenie pasowych technik łączenia wierzchu i spodu, stosowanych w obuwiu nowożytnym ${ }^{10}$.

Znaleziska opisanych wyżej butów z Pucka dowodzą, że taki zaawansowany sposób wzmocnienia obuwia wywracanego był znany i stosowany jeszcze wcześniej, bo już w drugiej połowie XIV w. W tym przypadku jednak dodatkowe spody nie były wszywane, lecz dołączane za pomocą drewnianych kołeczków lub metalowych ćwieków. Uwagę zwracają uszczelki w obu opisanych butach, do których przymocowano zewnętrzne wzmocnienia. Były one szersze od przeciętnych, zatem zamysł wzmocnienia podeszwy musiał powstać już na etapie produkcji. Czy jednak wyroby te można uznać za produkt miejscowych warsztatów?

Pewnych sugestii dostarczają nieliczne publikowane znaleziska obuwia wykonanego w konstrukcji wywracano-pasowej, w sposób analogiczny do wyżej omówionych. Najbliższe podobieństwo wykazuje but z Helgeandsholmen w Sztokholmie, datowany na XIV-XV w. ${ }^{11}$ Zachowany w nieco w lepszym stanie niż egzemplarz pucki reprezentuje ten sam typ — z rozciętą z przodu cholewką wiązaną rozdwojonym sznurowadłem. Jego dodatkowy spód, wykonany z nawet pięciu warstw skóry, połączonych ze sobą drewnianymi kołeczkami i przymocowany do szerokiej uszczelki (szw. Pliggsulan), obejmował całą powierzchnię podeszwy. Poza

7 Wywrot-Wyszkowska B. 2009, s. 159. W zbiorze z drugiej połowy XIV w. ok. czwarta część znalezisk podeszew nosiła ślady dodatkowych wzmocnień, z czego pewna część zewnętrznych, określanych jako zelówki i obcasy. Szczegóły opisu, takie jak zelówki z „kołnierzowato” uformowanymi krawędziami, które ściśle przylegały do brzegów podeszew oraz ścienione krawędzie podeszew, wskazują na inny niż omawiany w artykule, wywracany sposób mocowania dodatkowych warstw skóry, bez wykorzystywania w tym celu uszczelki. Niewątpliwie są one jednak wyrazem dążenia do wzmocnienia i podniesienia trwałości spodów obuwia.

${ }^{8}$ Grew F., Neergaard M. 1988, s. 47; Goubitz O., Driel-Murray C. van, Groenman-van Waateringe W. 2001, s. 91-92, 95.

9 Volken M. i S. 2007, s. 41-42.

${ }^{10}$ Goubitz O., Driel-Murray C. van, Groenman-van Waateringe W. 2001, s. 91-92; Blusiewicz K. 2009, s. 50.

11 Fredriksson M., Zerpe B. 1982, s. 224-225, ryc. 182. 


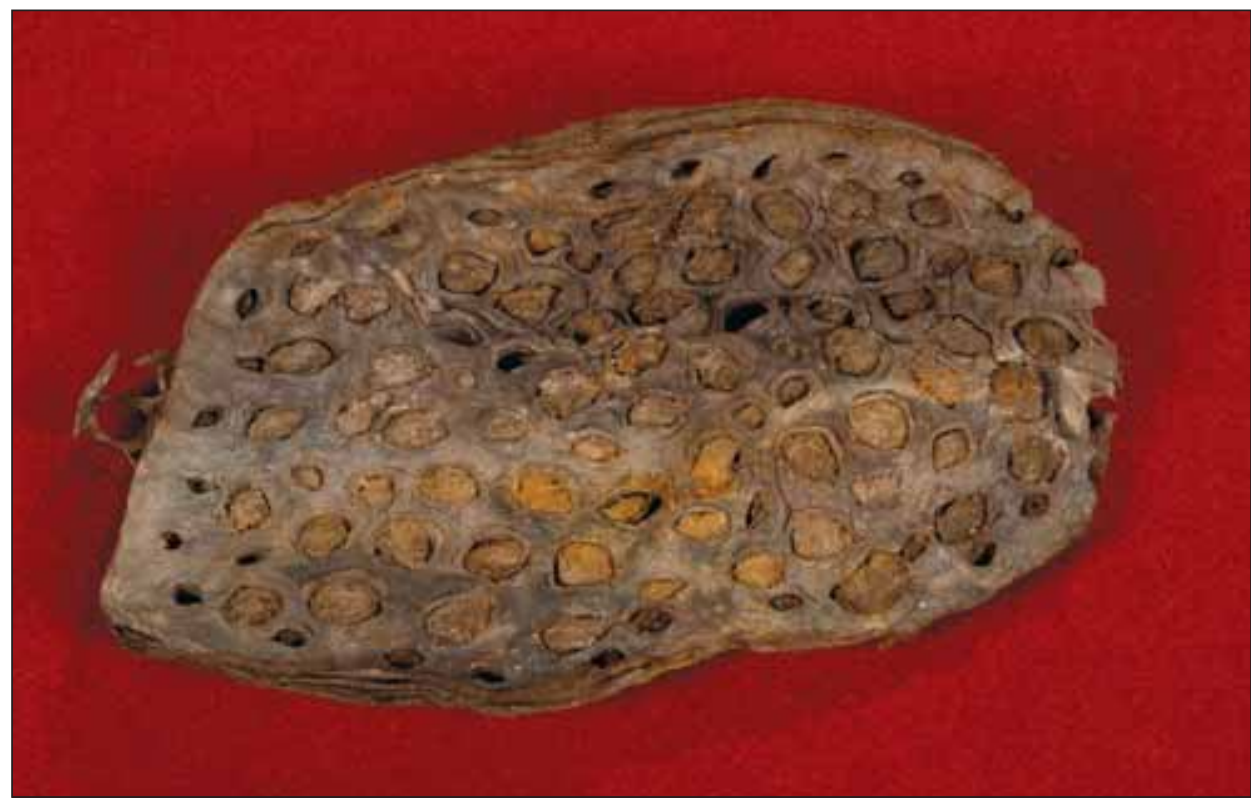

Ryc. 3. Kołkowane wzmocnienie przedstopia spodu obuwia z XIV-XV w. z badań Helgeandsholmen w Sztokholmie (https://stockholmskallan.stockholm.se/post/6858, dostęp 01.03.2020 r.)

Fig. 3. A wood-pinned sole from the 14th-15th c., from Helgeandsholmen in Stockholm (https://stockholmskallan.stockholm.se/post/6858, accessed 01.03.2020)

tym jednym egzemplarzem zachowanym wraz z wierzchem, z badań pozyskano 47 kołkowanych spodów oraz 525 ich fragmentów, datowanych na XIV i XV w. ${ }^{12}$ (ryc. 3).

Dość liczny zbiór, złożony z 24 fragmentów wielowarstwowych, kołkowanych spodów (wood-pinned outer sole) pochodzi z badań wykopaliskowych starego miasta $\mathrm{w}$ fińskim Turku ${ }^{13}$. Najstarsze wydobyto z nawarstwień z drugiej połowy XIV w., większość zaś z warstw datowanych szerzej na drugą połowę XIV i XV w. oraz XV po początek XVI stulecia. Składały się z kilku warstw skóry połączonej ze sobą gęsto rozmieszczonymi kołeczkami z drewna sosnowego, lipowego, brzozowego i topolowego. Regularny rząd kołeczków na obwodzie służył przymocowaniu go do szerokiej uszczelki, w dwóch oddzielnych częściach dla przedstopia i pięty. Nieznany jest wygląd tego obuwia, bowiem żadnen ze spodów nie zachował się z wierzchem.

Inne odnotowane i niezbyt liczne znaleziska obuwia z zewnętrzną, kołkowaną podeszwą pochodzą już z młodszych okresów. Fragment takiego spodu pozyskano z Lund, z wypełniska piętnastowiecznej studni, a egzemplarze datowane na wiek XVI z duńskiego Svendborga i estońskiej Parnawy ${ }^{14}$. Ze względu na dość ograniczony zasięg ich występowania Janne Harjula wysunął sugestię ich regionalnego, skandynawskiego pochodzenia ${ }^{15}$.

12 Fredriksson M., Zerpe B. 1982, s. 224.

13 Harjula J. 2008, s. 117-119.

14 Groenmann-van Waateringe W. 1988, s. 22, 32; Kadakas V. i in. 2002, s. 192-193; Harjula J. 2008, s. 119. W przypadku tych znalezisk publikowany opis nie pozwala jednak stwierdzić, w jaki sposób wielowarstwowa, kołkowana podeszwa łączona była z wierzchem obuwia. Na początku XVI w. znane są już wielowarstwowe podeszwy obuwia wykonanego np. techniką sandałową (Blusiewicz K. 2009, s. 122-125).

15 Harjula J. 2008, s. 119. 


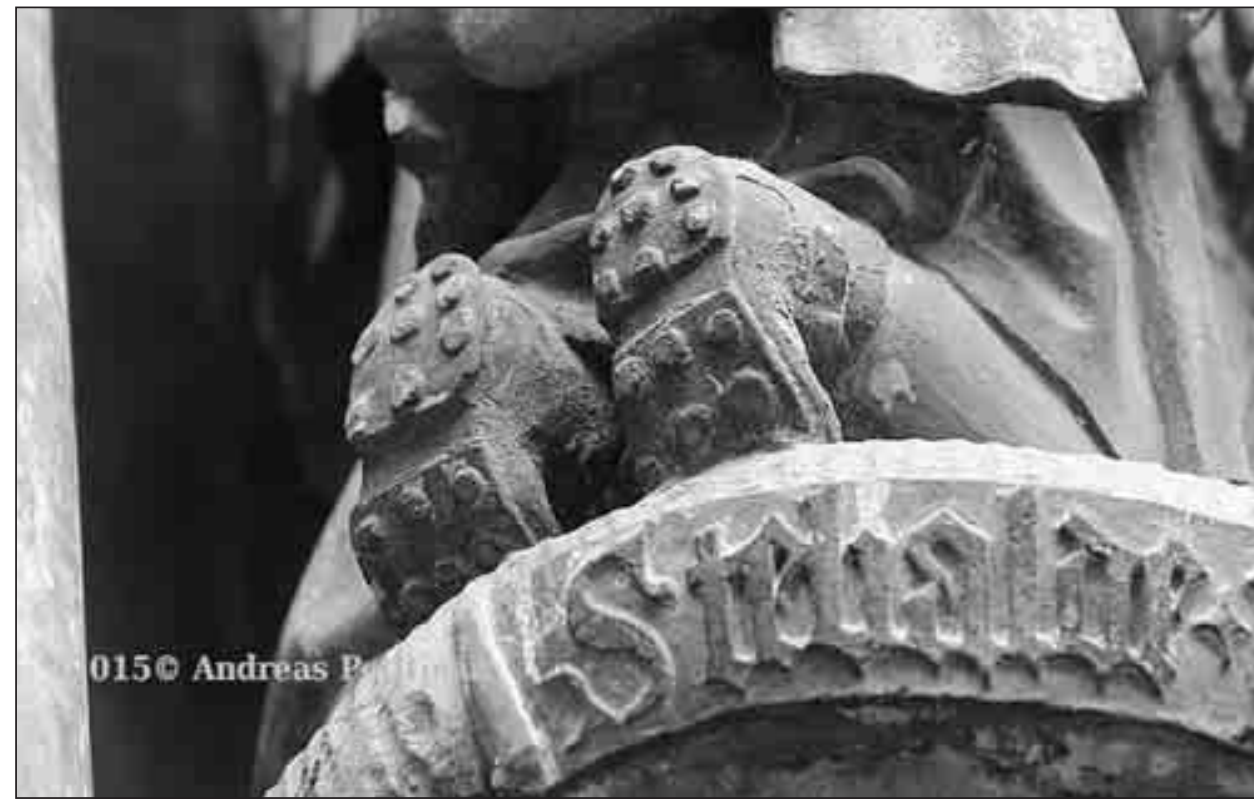

Ryc. 4. Fragment postaci pielgrzyma, Thann (Alzacja), 1430-1450, fot. A. Petitjean, za: Volken M. 2015, fig. 4 (https://www.researchgate.net/figure/Sculpture-of-a-pilgrim-prayingwith-nailed-repair-soles-Thann-DE-c-1430-50-Photo-by_fig7_321896798, dostęp 01.03.2020 r.)

Fig. 4. A fragment of the image of a pilgrim, Thann (Alsace), 1430-1450, photo by A. Petitjean, after: Volken M. 2015, fig. 4 (https://www.researchgate.net/figure/Sculpture-of-a-pilgrim-prayingwith-nailed-repair-soles-Thann-DE-c-1430-50-Photo-by_fig7_321896798, accessed 01.03.2020)

Jeszcze mniej informacji dotyczy obuwia ze wzmocnieniem zewnętrznym mocowanym metalowymi nitami. Stan zachowania zabytku z Pucka nie daje podstaw do wiarygodnej rekonstrukcji. Niewykluczone, że dodatkowa warstwa skóry (jedna lub wiele) nie tylko była dołączona metalowymi ćwiekami, ale także nabijana nimi na całej powierzchni. Na stosowanie takich rozwiązań wskazuje znaleziony w lokacyjnym Kołobrzegu „obcas” z drugiej połowy XIV w., w postaci grubej skóry nabijanej regularnie żelaznymi gwoździkami ${ }^{16}$. Obuwie ze spodem nabijanym widoczne jest na nogach modlącego się pielgrzyma, uwiecznionego rzeźbiarsko w drugiej ćwierci XV w. ${ }^{17}$ (ryc. 4).

Zastosowane wzmocnienia z pewnością podnosiły trwałość obuwia, wielowarstwowy spód w większym stopniu izolował stopę od wilgoci, zaś zastosowane ćwieki lub kołki zwiększały jego przyczepność do podłoża. Być może obuwie takie przeznaczone było celowo do długich wędrówek lub przemieszczania się po śliskich nawierzchniach. Odnotowane w literaturze znaleziska są jednak na tyle rzadkie, by wciąż wątpić w powszechne stosowanie tego typu ulepszeń w drugiej połowie XIV w. Choć nie wydaje się, by ich wykonanie wykraczało poza możliwości techniczne małomiasteczkowych szewców, zastanawiający jest brak innych śladów takiego, niewątpliwie istotnego wzmocnienia wśród dość licznych puckich znalezisk, w tym także z kolejnego stulecia. Przy obecnym stanie badań nie można ocenić, czy wynika to z pochodzenia znalezionych egzem-

16 Wywrot-Wyszkowska B. 2009, s. 162, ryc. 19:4.

17 Volken M. 2015, ryc. 4; również https://www.researchgate.net/figure/Sculpture-of-a-pilgrim-prayingwith-nailed-repair-soles-Thann-DE-c-1430-50-Photo-by_fig7_321896798 (dostęp 14.02.2020). Użyte w opisie ilustracji określenie obuwia jako naprawianego wydaje się nieuprawnioną nadinterpretacją. 
plarzy spoza miasta, braku odpowiednich umiejętności szewców puckich, czy też z innych powodów, takich jak wysoka cena lub brak zapotrzebowania na tak wzmocnione obuwie.

Pewną przesłanką w powyższych rozważaniach może być także fason omawianych egzemplarzy, wyróżniający się sposobem mocowania na stopie. Mimo licznych opracowań zbiorów archeologicznych z terenu obecnej Polski obuwie z cholewką wiązaną sznurowadłami przez pary dziurek zidentyfikowano jedynie w zbiorach późnośredniowiecznego obuwia z badań portu przy Głównym Mieście w Gdańsku ${ }^{18}$. Poza tym najbliższe analogie pochodzą ze wspomnianego już Helgeandsholmen w Sztokholmie ${ }^{19}$ oraz niderlandzkich Dordrechtu, Baarn i Lejdy ${ }^{20}$. But z cholewą zapinaną paskami został zrekonstruowany na podstawie licznych przykładów obuwia niderlandzkiego ${ }^{21}$. Najbliższe tego typu znaleziska pochodzą z Nowego Targu we Wrocławiu ${ }^{22}$ oraz miast niemieckich ${ }^{23}$.

W świetle powyższych ustaleń istnieje zatem znaczne prawdopodobieństwo, że dwa nietypowe buty z Pucka nie były wyrobem miejscowych rzemieślników. Bez wątpienia stanowią one przyczynek do dyskusji nad wciąż słabo rozpoznanym tematem przemian w późnośredniowiecznej produkcji szewskiej - ich czasu, kierunków napływu i upowszechniania się. Zagadnienia te wymagają dużej uwagi w odczytywaniu śladów konstrukcyjnych, a spojrzenie na nie będzie ulegać zmianom w miarę pojawiania się nowych, szczegółowych publikacji źródłowych.

Adres Autora

dr Karolina Blusiewicz

Instytut Archeologii UW

ul. Krakowskie Przedmieście 26/28

00-927 Warszawa

k.blusiewicz@uw.edu.pl

https://orcid.org/0000-0002-2771-9336

\section{BIBLIOGRAFIA}

Blusiewicz Karolina. 2009. Obuwie warszawskie w XIV-XVII wieku. Przemiany w technice szewskiej, [w:] Wytwórczość w Polsce średniowiecznej i nowożytnej, red. J. Chudziakowa, Archaeologia Historica Polona, t. 18, Toruń, s. 121-139.

Blusiewicz Karolina. 2017. Wyroby ze skóry i wytwórczość skórnicza w późnośredniowiecznym Pucku, [w:] Puck. Kultura materialna małego miasta w późnym średniowieczu, red. M. Starski, Warszawa, s. 305-360.

Fredriksson Monica, Zerpe Birgitta 1982. Skor och andra läderförmal, [w:] Helgeandsholmen, 1000 år i Stockholms ström, red. G. Dahlbäck, Stockholm, s. 217-240.

Goubitz Olaf, Driel-Murray Carol van, Groenman-van Waateringe Willy. 2001. Stepping trough Time. Archaeological Footwear from Prehistoric Times until 1800, Zwolle.

Grew Francis, Neergaard Margrethe. 1988. Shoes and pattens, London.

Groenman-van Waateringe Willy, Krauwer Monique. 1987. Das Leder von Lübeck, Grabungen Schüsselbuden 16/Fischstrasse 1-3 (01), „Lübecker Schriften zur Archäologie und Kulturgeschichte", Bd. 10, Lübeck.

Groenman-van Waateringe Willy. 1988. Leather from Medieval Svendborg, The Archaeology of Svendborg, Denmark, No 5, red. M. Jansen, Odense.

\footnotetext{
18 Wywrot-Wyszkowska B. 2010, s. 207.

19 Fredriksson M., Zerpe B. 1982, ryc. 182.

${ }^{20}$ Typ 65 wg O. Goubitza (Goubitz O., Driel-Murray C. van, Groenman-van Waateringe W. 2001, s. 191-191).

${ }^{21}$ Goubitz O., Driel-Murray C. van, Groenman-van Waateringe W. 2001, s. 214.

22 Konczewska M. 2018, s. 831, ryc. 710.

${ }^{23}$ M.in. z XIV i XV w. z Konstancji (Schnack C. 1994, s. 31-32, tabl. 34-35), z XV w. z Lubeki (Groen-
} man-van Waateringe W., Krauwer M. 1987, tabl. 62.5, 63.6). 
Groth Andrzej. 1998. Czasy Rzeczypospolitej Szlacheckiej, [w:] Historia Pucka, red. A. Groth, Gdańsk, s. $91-207$.

Harjula Janne. 2008. Before the Heels. Footwear and Shoemaking in Turku in the Middle Ages and at the Beginning of the Early Modern Period, Archaeologia Medii Aevi Finlandiae, t. XV, red. J. Harjula, Turku.

Kadakas Villu, Haak Arvi, Russow Erki, Saluäär Ulla, Sarv Krista. 2002. Archaeological investigations in Pärnu, Arheoloogilised välitööd Eestis, red. U. Tamla, Tallinn, s. 179-203.

Konczewska Magdalena. 2018. Odzież skórzana - obuwie, patynki, rękawice i inne elementy ubioru, [w:] Rytm rozwoju miasta na kulturowym pograniczu. Studium strefy placu Nowy Targ we Wrockawiu, cz. 2, Wratislavia Antiqua, t. 23, red. J. Piekalski, K. Wachowski, Wrocław, s. 794-849.

Samsonowicz Henryk. 1954. Rzemiosło wiejskie w Polsce XIV-XVII w., Warszawa.

Schnack Christine. 1994. Mittelalterliche Lederfunde aus Konstanz (Grabung Fischmarkt), Materialhefte zur Archäologie in Baden-Württemberg, t. 26, red. G. Wesselkamp, Stuttgart.

Volken Marquita. 2017. Arming shoes of the fifteenth century, „Acta Periodica Duellatorum”, 5 (2), s. $25-45$.

Volken Marquita, Volken Serge. 2007. Les cuirs des Halles du Molard 2-4 a Geneve, „Zeitschrift für Schweizer Archäologie und Kunstgeschichte", 64, s. 35-66.

Wywrot-Wyszkowska Beata. 2009. Uwagi na temat wytwórczości obuwniczej w późnośredniowiecznym Kołobrzegu, [w:] Wytwórczość w Polsce średniowiecznej i nowożytnej, red. J. Chudziakowa, Archaeologia Historica Polona, t. 18, Toruń, s. 141-167.

Wywrot-Wyszkowska Beata. 2010. Zabytki skórzane odkryte w obrębie późnośredniowiecznego portu gdańskiego, [w:] Archeologia Gdańska, t. IV, red. H. Paner, Gdańsk, s. 189-224.

Two atypical shoes from Puck from the late 14th c.

Among the many remains of footwear revealed in the excavations carried out in the area of the chartered town in Puck, there were two pieces atypical in terms of the fastening and production technique. Both were found in the waste of a shoe-maker's workshop, whose relicts were dated dendrochronologically to the 4th quarter of the 14th century.

One of them was a large-size man's shoe with a high upper slit at the front, fastened with a split lace (Fig. 1). Its whole-cut upper was made of cowhide, with an insert; it was reinforced with a heel stiffener made of sheep or goat skin; and the topedge had an top band. A fragment of inner lining has survived, in the form of the underside layer of skin, whose structure indicated that it had not come from grown-up cattle. The lining may have been made of split leather or of full-grain leather whose grain was fully delaminated. The sole and the upper were joined by the turn-welt construction method, with an additional wood-pinned outer sole.

The other find was also a man's shoe, with a high upper slit at the front, fastened with at least two belts with holes and - most probably - metal buckles (Fig. 2.). Its whole-cut upper was made of calfskin, with an insert; the back was reinforced with a wide heel stiffener and the top edge with a top binding. The sole, of the turn-welt construction, was reinforced inside with a heel seat and on the outside with extra pieces in the forefoot and heel areas. The outside reinforcement left a regular line of holes on the wide rand (Fig. $2 \mathrm{~g}$ ). Traces of corrosion indicate that the outer sole was fixed with hobnails. Apart from that, the welt shows some irregular holes with remnants of a leather band, which are probably traces of repairs or of exchanging the reinforcement parts.

The shoes/footwear from Puck are a very early example of applying the turn-welt construction; there have been no analogical finds in Poland so far. Their construction and fastening, as well as the location of the sites where analogical finds have been revealed, suggest that they were not produced in the local workshop. 